\title{
Red and Blue Compounds Formed from Copper(II) Bromide and the Ligand 7-Isobutyl-5-methyl-[1,2,4]triazolo [1,5-a]pyrimidine: Synthesis, Spectroscopy and Single-Crystal Structures
}

\author{
Esref Günay · Ilpo Mutikainen · Urho Turpeinen • \\ Gerard A. van Albada · Jaap G. Haasnoot • \\ Jan Reedijk
}

Received: 4 November 2009/Accepted: 13 May 2010/Published online: 29 May 2010

(C) The Author(s) 2010. This article is published with open access at Springerlink.com

\begin{abstract}
Two newly synthesized coordination compounds copper(II) bromide with the ligand 7-isobutyl-5-methyl[1,2,4] triazolo[1,5- $a$ ]pyrimidine (abbreviated as ibmtp) are presented, together with their 3D crystal structure and spectroscopic and magnetic properties. The compounds are $\mathrm{CuBr}_{2}(\mathrm{ibmtp})_{2}$ (1) (red crystals) and $\left[\mathrm{CuBr}(\mathrm{ibmtp})_{4}\right] \mathrm{Br}\left(\mathrm{H}_{2} \mathrm{O}\right)_{3}(\mathbf{2})$ (blue crystals). In (1) the $\mathrm{Cu}$ (II) ion is present in a distorted tetrahedral environment, while in (2) the $\mathrm{Cu}$ (II) ion has a square pyramidal geometry. These crystal structures are also the first ones reported with the ligand ibmtp.
\end{abstract}

Keywords Copper $\cdot$ Bromide $\cdot$ Triazolopyrimidine

\section{Introduction}

Triazolopyrimidines (IUPAC recommended name: $[1,2,4]$ triazolo[1,5-a]pyrimidines) are versatile ligands, as they have several nitrogen atoms with accessible lone pairs to bind to Lewis acids like metal ions. The unsubstituted ligand is abbreviated as tp.

These ligands have a fused 5-membered and 6-membered ring system and as such resemble the nucleobases adenine

Electronic supplementary material The online version of this article (doi:10.1007/s10870-010-9785-8) contains supplementary material, which is available to authorized users.

E. Günay · G. A. van Albada · J. G. Haasnoot · J. Reedijk ( $\square)$ Leiden Institute of Chemistry, Leiden University,

P.O. Box 9502, 2300 RA Leiden, The Netherlands

e-mail: reedijk@chem.leidenuniv.nl

I. Mutikainen · U. Turpeinen

Laboratory of Inorganic Chemistry, Department of Chemistry,

University of Helsinki, A.I.Virtasenaukio 1, P.O. Box 55,

Helsinki 00014, Finland and guanine of DNA. A variety of coordination compounds of metals salts with the parent ligand and other triazoles is already known and reviewed [1,2]. Previous work from this laboratory has mainly been focusing on methyl substituted triazolopyrimidine-based ligands [2-11]. Also other groups have been studying these types of ligands [12-17]. Triazoles and pyrimidines may act as bridging ligands between metals via N3-N4 (see Scheme 1), but may also coordinate monodentately via N3 [18-20].

In a more recent paper we reported on transition metal compounds with the ligands (5,7-diethyl[1,2,4]triazolo[1, 5-a]pyrimidine), (5-methyl,7-phenyl[1,2,4]triazolo[1,5-a]pyrimidine) [21] and most recently (5,6,7-trimethyl[1,2,4]triazolo [1,5-a]pyrimidine) [22]. The steric effects of substituents in these ligands are interesting and had not yet been explored before in great detail. In the present study we report on two different copper bromide compounds with the new ligand (7-isobutyl-5-methyl$[1,2,4]$ triazolo[1,5-a]pyrimidine) (abbreviated as ibmtp).

The ligand ibmtp was selected, as it contains a large isobutyl substituent on the seventh position. So far, to the best of our knowledge, no other coordination compounds have been reported with the ligand ibmtp.

In this study we report on two $\mathrm{Cu}$ (II) compounds, prepared via different synthetic routes, i.e. $\mathrm{CuBr}_{2}(\mathrm{ibmtp})_{2}$ (1) (red crystals) and $\left[\mathrm{CuBr}(\mathrm{ibmtp})_{4}\right] \mathrm{Br}\left(\mathrm{H}_{2} \mathrm{O}\right)_{3}$ (2) (blue crystals).

\section{Experimental Part}

Starting Materials

Hydrated metal salts, solvents, the diketone and 5-amino1,2,4-triazole were used as commercially available, without further purification. 
Scheme 1 The ligand

7-isobutyl-5-methyl-

$[1,2,4]$ triazolo $[1,5$-a]pyrimidine

(ibmtp) and its IUPAC

recommended ring-atom

numbering system

Synthesis of the Ligand

The synthesis of the ligand ibmtp was carried out by a known condensation procedure $[2,23]$ at $160{ }^{\circ} \mathrm{C}$, from 6-methylheptane-2,4-dione and 3-amino-1,2,4-triazole. Details: $21 \mathrm{~g}$ $(0.25 \mathrm{~mol})$ of 3-amino-1,2,4-triazole and $35.6 \mathrm{~g}(0.25 \mathrm{~mol})$ 6-methyl-2,4-heptanedione were put into a beaker glass and about $100 \mathrm{~mL}$ of ethylene glycol was added. The mixture was heated for about $1 \mathrm{~h}$ at around $160{ }^{\circ} \mathrm{C}$. The mixture was cooled at RT and about $100 \mathrm{~mL}$ of ethanol was added and stirred. Overnight in the refrigerator the product separated and was subsequently filtered and washed with cold ethanol. Yield ca. 50\%. Elemental Analysis calc. (found) for $\mathrm{C}_{10} \mathrm{H}_{14} \mathrm{~N}_{4}: 62.9$ (63.1) \%C, 7.2 (7.4) \% H, 29.3 (29.5) \% N. For the IR spectrum see Fig. S1; the characterization of the specific isomer was made by $\mathrm{X}$-ray diffraction (vide infra).

Synthesis of the Coordination Compounds

Synthesis of (1): A solution of $2 \mathrm{mmol}(450 \mathrm{mg})$ of $\mathrm{CuBr}_{2}$ in $20 \mathrm{~mL}$ of water was added to a warm aqueous solution of $2 \mathrm{mmol}(380 \mathrm{mg})$ of ibmtp. Upon standing at room temperature red crystals appeared after one or 2 weeks, which were collected by filtration. Yield: about $30 \%$. Anal. Calcd for $\mathrm{C}_{20} \mathrm{H}_{28} \mathrm{Br}_{2} \mathrm{CuN}_{8}$ : C, 39.8; $\mathrm{H}, 4.7 ; \mathrm{N}, 18.6 \%$; Found: C, 39.7; H, 4.6; N, 18.6\%.

Synthesis of (2): $1 \mathrm{mmol}(240 \mathrm{mgr})$ of $\mathrm{Cu}\left(\mathrm{NO}_{3}\right)_{2} \cdot 3 \mathrm{H}_{2} \mathrm{O}$ and $2 \mathrm{mmol}(380 \mathrm{mg})$ of ibmtp were each dissolved in mixture of $20 \mathrm{~mL}$ of water/ethanol (1:1) and put carefully together. The solution stays clear and after one day $2 \mathrm{mmol}$ (240 mgr) of $\mathrm{KBr}$ dissolved in $5 \mathrm{~mL}$ water was added. After a few days blue crystals appeared. Yield ca. $60 \%$. Anal. Calcd for $\mathrm{C}_{40} \mathrm{H}_{62} \mathrm{Br}_{2} \mathrm{CuN}_{16} \mathrm{O}_{3}: \mathrm{C}, 46.3 ; \mathrm{H}, 6.0 ; \mathrm{N}$, 21.6\%; Found: C, 46.1; H, 5.9; N, 21.6\%.

Physical and Analytical Methods

$\mathrm{C}, \mathrm{H}, \mathrm{N}$ determinations were performed on a PerkinElmer 2400 Series II analyzer. Ligand field spectra in the 300-2000 nm range were obtained on a PerkinElmer Lambda 900 spectrophotometer using the diffuse reflectance technique, using $\mathrm{MgO}$ as a reference. Infrared spectra of all compounds were recorded on a PerkinElmer Paragon 1000 FTIR spectrophotometer equipped with a Golden Gate ATR device, using the reflectance technique
(4000-300 $\mathrm{cm}^{-1}$, res. $4 \mathrm{~cm}^{-1}$ ). X-band powder EPR spectra were obtained on a Bruker EMXplus electron spin resonance spectrometer at room $\mathrm{T}$ and $77 \mathrm{~K}$ (Field calibrated with DPPH $(\mathrm{g}=2.0036))$.

\section{X-Ray Diffraction Studies}

For each coordination compound a suitable crystal was selected from the mother liquid and mounted to a glass fibre using the oil-drop method [24]. Diffraction data were collected on a Nonius KappaCCD diffractometer (graphitemonochromated $\mathrm{MoK} \alpha$ radiation). The structures were solved by direct methods. The programs COLLECT [25], SHELXS-97 [26] SHELXL-97 [26] were used for data reduction, structure solution and structure refinement, respectively. Refinement of $\mathrm{F}^{2}$ was performed against all reflections. All non-hydrogen atoms were refined anisotropically. Details for compound 1: All $\mathrm{H}$ atoms were introduced in calculated positions and refined with fixed geometry with respect to their carrier atoms. Details for compound 2: One of the water molecules was found to be disordered and refined in two positions. The uncoordinated bromide anion was found to be severely disordered and was refined in four positions. The hydrogen atoms of the water molecules were not located nor fixed. All other $\mathrm{H}$ atoms were introduced in calculated positions and refined with fixed geometry with respect to their carrier atoms.

Crystallographic data of the compounds are summarized in Table 1.

\section{Results and Discussion}

Description of the X-Ray Structures

Crystal Structure of $\mathrm{CuBr}_{2}(\text { ibmtp) })_{2}(1)$

An ORTEP perspective view of $\mathbf{1}$ is presented in Fig. 1. Selected bond lengths and angles are given in Table 2. A two-fold axis relates the 2 halves of the molecule. The $\mathrm{Cu}$ (II) ion has a distorted tetrahedral environment formed by two nitrogen atoms of two ibmtp ligands $(\mathrm{Cu}-\mathrm{N}$ distance $1.986(2) \AA$ ) and two coordinated bromide anions (Cu-Br distance 2.3602(4) $\AA$ ). Such tetrahedrally-based distorted geometries are not uncommon for $\mathrm{Cu}(\mathrm{II})$ with $\mathrm{N}$ donor ligands [27]. The $\mathrm{N}-\mathrm{Cu}-\mathrm{Br}$ angle is $137.11(6)^{\circ}$. The $\mathrm{Cu}-\mathrm{N}$ and $\mathrm{Cu}-\mathrm{Br}$ bond distances are in typical ranges for this type of $\left[\mathrm{CuN}_{2} \mathrm{Br}_{2}\right]$ tetrahedrally based compounds [28, 29]. This structure can also be compared with $\left[\mathrm{CuBr}_{2}\right.$ (tmtp) $)_{2}$ [ [22] (tmtp = 5,6,7-trimethyltriazolopyrimidine). The $\left[\mathrm{CuBr}_{2}(\mathrm{tmtp})_{2}\right]$ structure contains two almost identical independent crystallographic units, and each of them is very similar to compound 1 . The $\mathrm{N}-\mathrm{Cu}-\mathrm{Br}$ and $\mathrm{Br}-\mathrm{Cu}-\mathrm{Br}$ 
Table 1 Crystallographic data

\begin{tabular}{|c|c|c|}
\hline & Compound (1) & Compound(2) \\
\hline Formula & $\mathrm{C}_{20} \mathrm{H}_{28} \mathrm{Br}_{2} \mathrm{CuN}_{8}$ & $\mathrm{C}_{40} \mathrm{H}_{56} \mathrm{Br}_{2} \mathrm{CuN}_{16} \mathrm{O}_{3}$ \\
\hline Molecular weight & 603.86 & 1032.36 \\
\hline Crystal system & Hexagonal & Tetragonal \\
\hline Temp (K) & $173(2)$ & $173(2)$ \\
\hline Space group & $\mathrm{P} 3_{1} 2_{1}$ & $\mathrm{P} 4 / \mathrm{nnc}$ \\
\hline$a(\AA)$ & $8.9326(9)$ & $13.413(2)$ \\
\hline$b(\AA)$ & $8.9326(9)$ & $13.413(2)$ \\
\hline$c(\AA)$ & $26.3330(3)$ & $28.006(5)$ \\
\hline$\alpha\left({ }^{\circ}\right)$ & 90 & 90 \\
\hline$\beta\left({ }^{\circ}\right)$ & 90 & 90 \\
\hline$\gamma\left({ }^{\circ}\right)$ & 120 & 90 \\
\hline$V\left(\AA^{3}\right)$ & $1819.6(3)$ & $5038.5(14)$ \\
\hline$Z$ & 3 & 4 \\
\hline$D_{\text {calc }}\left(\mathrm{g} \mathrm{cm}^{-3}\right)$ & 1.653 & 1.369 \\
\hline$F(000)$ & 909 & 2148 \\
\hline$\mu\left(\mathrm{mm}^{-1}\right)$ & 4.218 & 2.071 \\
\hline Crystal size (mm) & $0.28 \times 0.22 \times 0.15$ & $0.35 \times 0.20 \times 0.08$ \\
\hline colour, shape & Red, block & Blue, plate \\
\hline$\theta \min , \theta \max \operatorname{deg}$ & $3.08-26.50$ & $2.66-25.05$ \\
\hline Total refl. & 23863 & 25938 \\
\hline Total unique refl. & $2509\left(R_{\mathrm{int}}=0.0514\right)$ & $2220\left(R_{\mathrm{int}}=0.0659\right)$ \\
\hline No.of refined parameters & 144 & 151 \\
\hline$R^{\mathrm{a}}, w R 2^{\mathrm{b}}$ & $0.0240,0.0521$ & $0.0487,0.1216$ \\
\hline$S^{c}$ & 1.101 & 1.093 \\
\hline min. and max. resd.dens. $\left(\mathrm{e} / \AA^{3}\right)$ & $0.210 ;-0.349$ & $0.654 ;-0.817$ \\
\hline
\end{tabular}

${ }^{\mathrm{a}} R 1=\Sigma|| F_{\mathrm{o}}|-| F_{\mathrm{c}}|| / \Sigma\left|F_{\mathrm{o}}\right|$,

${ }^{\mathrm{b}} w R 2=\left[\Sigma\left[w\left(F_{\mathrm{o}}^{2}-F_{\mathrm{c}}^{2}\right)^{2}\right] /\right.$

$\left.\Sigma\left[w\left(F_{\mathrm{o}}^{2}\right)^{2}\right]\right]^{1 / 2}$

c Goodness-of-fit

$\mathrm{S}=\left[\Sigma \mathrm{w}\left(F_{o}^{2}-F_{c}^{2}\right)^{2} /(n-p)\right]^{1 / 2}$,

where $n$ is the number of

reflections and $p$ the number of parameters

\section{IR, Ligand Field and EPR Spectroscopy}

For characterisation purpose the IR spectra are given in the supplementary material (Figs. S2, S3), the characteristic the ligand vibrations differ only slightly as can be expected. In compound (2) at around $3420 \mathrm{~cm}^{-1}$ a broad absorption is observed, which is due to $v \mathrm{OH}$ of the lattice water molecules.

The powder EPR spectra of both compounds (see Figs. $\mathrm{S} 4, \mathrm{~S} 5$ ) reveal at $\mathrm{RT}$ a typical $\mathrm{S}=1 / 2$ spectrum with a $\mathrm{g}_{\text {perp }}$ of 2.08 and a strong unresolved $\mathrm{g}_{/ /}$of 2.31 for compound (1) and with a $g_{\text {perp }}$ of 2.07 and a very weak unresolved $g_{/ /}$ of 2.31 for compound (2). These signals are in agreement with a $d_{x 2-y 2}$ configuration for the ground state [30].

The ligand-field transitions measured as a solid with the diffuse reflectance technique (see Figs. S6, S7) observed for compound (1) a very broad tail shaped band which a centre around $9.9(7.7 \mathrm{sh}) \times 10^{3} \mathrm{~cm}^{-1}$, and is assigned to the split but unresolved $d-d$ transition ${ }^{2} \mathrm{~T}_{2 \mathrm{~g}} \rightarrow{ }^{2} \mathrm{E}_{\mathrm{g}}$. For compound (2) a broad band at $14.3 \times 10^{3} \mathrm{~cm}^{-1}$, assigned to the d-d transition ${ }^{2} \mathrm{E}_{\mathrm{g}} \rightarrow{ }^{2} \mathrm{~T}_{2 \mathrm{~g}}$, with a shoulder at about $10.1 \times 10^{3} \mathrm{~cm}^{-1}$, assigned to a split component of the $\mathrm{d}-\mathrm{d}$ transition ${ }^{2} \mathrm{E}_{\mathrm{g}} \rightarrow{ }^{2} \mathrm{~T}_{2 \mathrm{~g}}$ was observed. These bands are not uncommon for ligand field transitions of tetrahedrally-based 


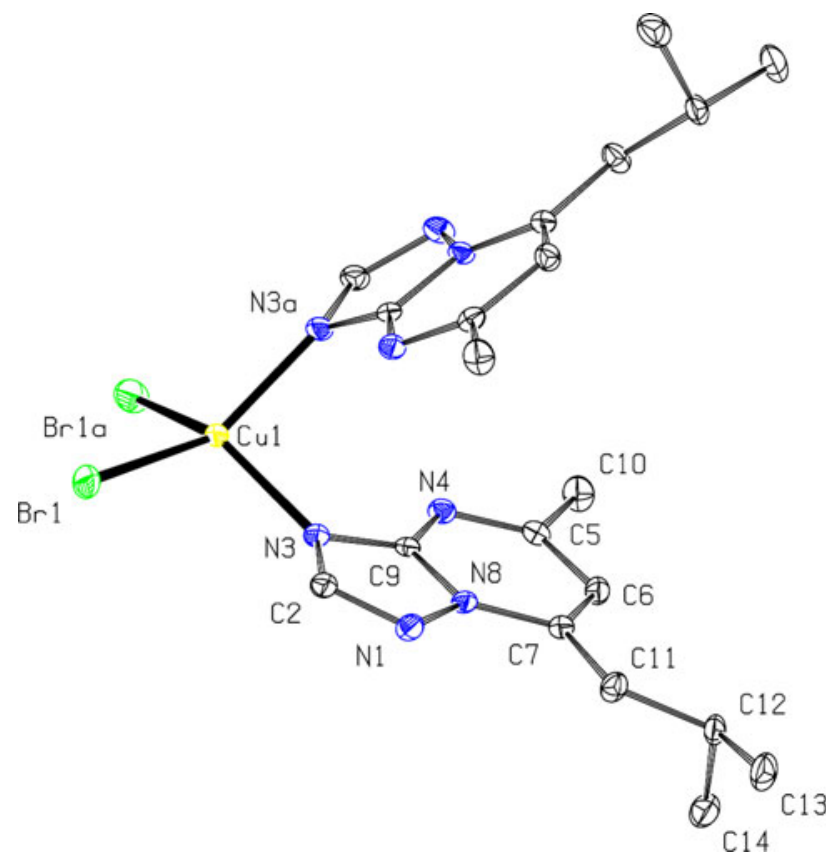

Fig. 1 ORTEP drawing (50\% probability level) of $\left[\mathrm{CuBr}_{2}(\mathrm{ibmtp})_{2}\right]$ (1). Hydrogen atoms are omitted for clarity

Table 2 Selected bond lengths $(\AA)$ and angles $\left({ }^{\circ}\right)$ of $\mathrm{CuBr}_{2}(\mathrm{ibmtp})_{2}(\mathbf{1})$

\begin{tabular}{llll}
\hline $\mathrm{Cu}(1)-\mathrm{N}(3)$ & $1.986(2)$ & $\mathrm{Cu}(1)-\mathrm{Br}(1)$ & $2.3602(4)$ \\
$\mathrm{N}(3)-\mathrm{Cu}(1)-\mathrm{N}(3) \mathrm{a}$ & $91.98(11)$ & $\mathrm{N}(3)-\mathrm{Cu}(1)-\mathrm{Br}(1)$ & $97.57(5)$ \\
$\mathrm{N}(3) \mathrm{a}-\mathrm{Cu}(1)-\mathrm{Br}(1)$ & $137.11(6)$ & $\mathrm{Br}(1)-\mathrm{Cu}(1)-\mathrm{Br}(1) \mathrm{a}$ & $103.06(2)$ \\
\hline
\end{tabular}

$\mathrm{a}=\mathrm{y}, \mathrm{x},-\mathrm{z}$

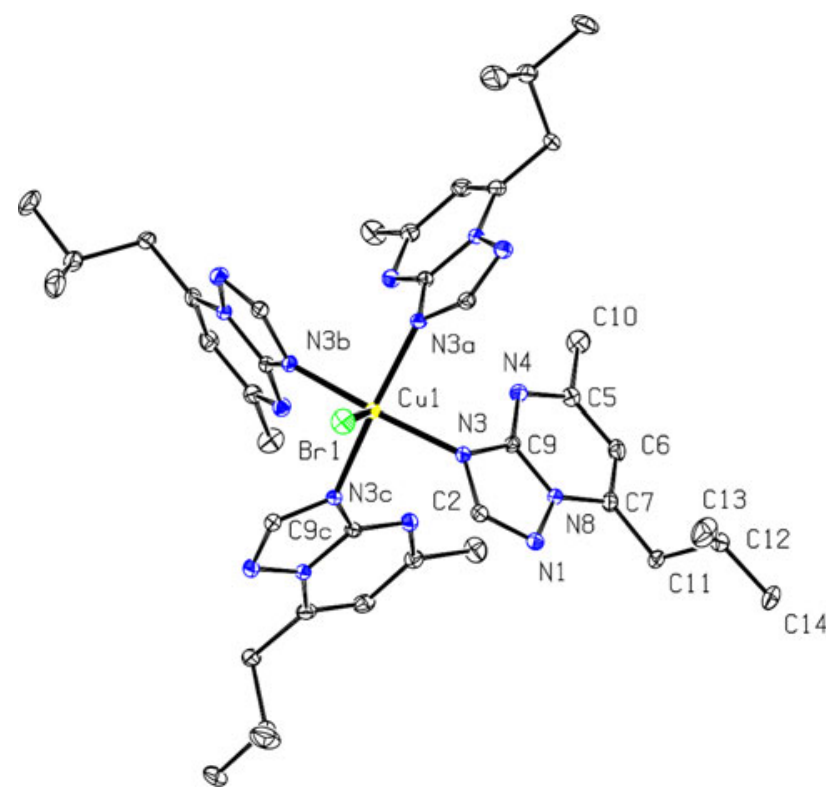

Fig. 2 ORTEP drawing (50\% probability level) of [CuBr(ibmtp $\left.)_{4}\right]$ $\mathrm{Br}\left(\mathrm{H}_{2} \mathrm{O}\right)_{3}(2)$. Hydrogen atoms, the uncoordinated bromide anion and lattice water molecules are omitted for clarity
Table 3 Selected bond lengths $(\AA)$ and angles $\left({ }^{\circ}\right)$ of $\left[\mathrm{CuBr}(\mathrm{ibmtp})_{4}\right]$ $\mathrm{Br}\left(\mathrm{H}_{2} \mathrm{O}\right)_{3}(2)$

\begin{tabular}{lclc}
\hline $\mathrm{Cu}(1)-\mathrm{N}(3)$ & $2.020(3)$ & $\mathrm{Cu}(1)-\mathrm{Br}(1)$ & $2.569(1)$ \\
$\mathrm{N}(3) \mathrm{a}-\mathrm{Cu}(1)-\mathrm{N}(3)$ & $88.56(3)$ & $\mathrm{N}(3)-\mathrm{Cu}(1)-\mathrm{N}(3) \mathrm{b}$ & $161.6(2)$ \\
$\mathrm{N}(3)-\mathrm{Cu}(1)-\mathrm{N}(3) \mathrm{c}$ & $88.56(3)$ & $\mathrm{N}(3)-\mathrm{Cu}(1)-\mathrm{Br}(1)$ & $99.13(9)$ \\
\hline $\mathrm{a}=\mathrm{y},-\mathrm{x}+1 / 2, \mathrm{z} ; \mathrm{b}=-\mathrm{x}+1 / 2,-\mathrm{y}+1 / 2, \mathrm{z} ; \mathrm{c}=-\mathrm{y}+1 / 2, \mathrm{x}, \mathrm{z}$
\end{tabular}

and square-planar based geometries, respectively and in agreement with the crystal structures found [30, 31].

\section{Concluding Remarks}

The study described above has presented two new $\mathrm{Cu}$ (II) compounds with a triazolopyrimidine ligand. The metalligand ratio determines the stoichiometry of the formed compounds. The anhydrous compound (1) shows no lattice hydrogen bonding, whereas the hydrate shows an interesting $\mathrm{Br}-\mathrm{O}$ hydrogen bonding pattern. The ligand synthesis, although in potential yielding two isomers, i.e. with the methyl group at either five of seven position, only yields a single isomer. The structure of the isomer is intrinsically also proven by the structure of the formed $\mathrm{Cu}$ (II) coordination compounds.

\section{Supplementary Data}

IR, LF and EPR spectra are given as supplementary material, Figs. S1-S7. CCDC- 751873 \& 751874 contains the supplementary crystallographic data for $\mathbf{1}$ and $\mathbf{2}$. These data can be obtained free of charge via http://www.ccdc. cam.ac.uk/conts/retrieving.html, or from the Cambridge Crystallographic Data Centre, 12 Union Road, Cambridge CB2 1EZ, UK; fax: (+44) 1223-336-033; or e-mail: deposit@ccdc.cam.ac.uk.

Acknowledgements This work was performed in the framework of freshmen students research project "Leren Onderzoeken 1" (Learning Research 1) in the BSc programme "Molecular Science and Technology" a recently started concept in the joint programme of Delft University of Technology and Leiden University.

Open Access This article is distributed under the terms of the Creative Commons Attribution Noncommercial License which permits any noncommercial use, distribution, and reproduction in any medium, provided the original author(s) and source are credited.

\section{References}

1. Salas JM, Romero MA, Sanchez MP, Quiros M (1999) Coord Chem Rev 195:1119

2. Haasnoot JG (2000) Coord Chem Rev 200:131 
3. Biagini-Cingi M, Manotti-Lanfredi AM, Tiripicchio A, Cornelissen JP, Haasnoot JG, Reedijk J (1987) Inorg Chim Acta 127: 189

4. Biagini Cingi M, Manotti Lanfredi AM, Tiripicchio A, Haasnoot JG, Reedijk J (1986) Acta Cryst C42:1509

5. Biagini Cingi M, Manotti Lanfredi AM, Tiripicchio A, Haasnoot JG, Reedijk J (1984) Inorg Chim Acta 86:137

6. Dirks EJ, Haasnoot JG, Kinneging AJ, Reedijk J (1987) Inorg Chem 26:1902

7. Lenstra ATH, Slot HJB, Beurskens PT, Haasnoot JG, Reedijk J (1989) Recl Trav Chim Pays-Bas 108:133

8. Sanni SB, Behm H, Beurskens PT, Cornelissen JP, Haasnoot JG, Lenstra ATH (1987) J Crystall Spectr Res 17:81

9. Szlyk E, Wojtczak A, Jaskolski M, Gilski M, Haasnoot JG, Reedijk J (1997) Inorg Chim Acta 260:145

10. van Albada GA, de Graaff RAG, Haasnoot JG, Schild J, Reedijk J (1991) Acta Crystallogr Sect C-Cryst Struct Commun 47:946

11. Velders AH, Bergamo A, Alessio E, Zangrando E, Haasnoot JG, Casarsa C, Cocchietto M, Zorzet S, Sava G (2004) J Med Chem 47:1110

12. Lakomska I, Szlyk E, Sitkowski J, Kozerski L, Wietrzyk J, Pelczynska M, Nasulewicz A, Opolski A (2004) J Inorg Biochem 98:167

13. Lakomska I, Wojtczak A, Sitkowski J, Kozerski L, Szlyk E (2007) Polyhedron 26:803

14. Romero MA, Salas JM, Quiros M, Williams DJ, Molina J (1993) Trans Met Chem 18:595

15. Salas JM, Enrique C, Romero MA, Takagi K, Aoki K, Miyashita Y, Suh IH (1992) Polyhedron 11:2903

16. Szlyk E, Lakomska I, Surdykowski A, Glowiak T, Pazderski L, Sitkowski J, Kozerski L (2002) Inorg Chim Acta 333:93
17. Szlyk E, Pazderski L, Lakomska I, Kozerski L, Sitkowski J (2002) Magn Reson Chem 40:529

18. Bencini A, Gatteschi D, Zanchini C, Haasnoot JG, Prins R, Reedijk J (1985) Inorg Chem 24:2812

19. Ferrer S, Haasnoot JG, Reedijk J, Muller E, Biagini-Cingi M, Lanfranchi M, Manotti-Lanfredi AM, Ribas J (2000) Inorg Chem 39:1859

20. Riggio I, van Albada GA, Mutikainen I, Turpeinen U, Reedijk J (2000) Acta Cryst Sect C-Cryst Struct Commun 56:E380

21. Balkaran JM, van Bezouw SCP, van Bruchem J, Verasdonck J, Verkerk PC, Volbeda AG, Mutikainen I, Turpeinen U, van Albada GA, Gamez P, Haasnoot JG, Reedijk J (2009) Inorg Chim Acta $362: 861$

22. Adriaanse JH, Askes SHC, van Bree Y, van Oudheusden S, Van den Bos ED, Günay E, Mutikainen I, Turpeinen U, van Albada GA, Haasnoot JG, Reedijk J (2009) Polyhedron 28:3143

23. Bülow C, Haas K (1909) Chem Ber 42:4638

24. Kottke T, Stalke D (1993) J Appl Crystallogr 26:615

25. Nonius, COLLECT (2002) Nonius BV. Delft, The Netherlands

26. Sheldrick GM (2008) Acta Cryst (A) 64:112

27. Estes WE, Hatfield WE, van Ooijen JAC, Reedijk J (1980) J Chem Soc Dalton Trans 1980:2121

28. Sanni SB, Smits JMM, Beurskens PT, Haasnoot JG, Schild J, Lenstra ATH (1986) J Crystallogr Spectrosc Res 16:823

29. Celik O, Ide S, Kurt M, Yurdakul S (2004) Acta Crystallogr E 60:M424

30. Hathaway BJ (1987) In: Wilkinson G, McCleverty JA (eds) Comprehensive coordination chemistry, vol 5. Pergamon Press, Oxford

31. Reedijk J, Driessen WL, Groeneveld WL (1969) Recl Trav Chim Pays-Bas 88:1095 